\title{
Usaha Produksi Kerajinan Sapu Berbahan Serabut Kelapa Berbasis Wilayah
}

\author{
Didin Hadi Saputra1*, Meiyanti Widyaningrum2, Samsul Bahri3
}

1,2,3 University of Nahdlatul Wathan Mataram

\author{
A R T I C L E I N F O \\ Article history: \\ Received 19 Januari 2018 \\ Received in revised form \\ 12 Februari 2018 \\ Accepted 28 Maret 2018 \\ Available online $20 \mathrm{Mei}$ \\ 2018 \\ Kata Kunci: \\ usaha bersama, Namira \\ dan Bina Taruna, Program \\ Kemitraan Masyarakat, \\ Sapu dari Serabut Kelapa, \\ Desa Telaga Waru \\ Keywords: \\ Business together, \\ Namira and Bina \\ Taruna, Community \\ Partnership Program \\ broom made from \\ coconut fiber, Telaga \\ Waru Village
}

\begin{abstract}
A B S T R A K
Usaha sapu serabut kelapa yang dibuat oleh Kelompok Namira dan Bina Taruna adalah sebuah usaha yang telah berjalan lancar dengan mitra di desa Telaga Waru, Kecamatan Pringgabaya ,Kabupaten Lombok Timur. Fokus dari kegiatan ini adalah bagaimana cara mengawasi keseluruhan proses manajemen usaha itu untuk mengelola dan mendokumentasikan hasil usaha serabut kelapa melalui media pemasaran untuk menghasilkan output atau hasil akhir yang lebih optimal dan efektif. Aktivitas program kemitraan ini bertujuan untuk meningkatkan kualitas dari produk serabut kelapa yang berlokasi di desa Telaga Waru, Kecamatan Pringgabaya, Kabupaten Lombok Timur. Metode implementasi dari program kemitraan masyarakat ini ditawarkan dengan mengusulkan tim kepada dua mitra termasuk koordinasi kelompok mitra yang ada, penyiapan jadwal kegiatan, bantuan pengembangan keterampilan kelompok mitra, pemasaran melalui bantuan, pengorganisasian produk open house yang dijadwalkan dan memfasilitasi liputan media cetak. Hasil dari pengabdian ini telah dapat dirasakan oleh seluruh masyarakat desa Telaga War dan wilayah sekitarnya setelah para peserta mengikuti proses sosialisasi dan proses ilmiah yang diberikan melalui praktek langsung dan proses dialog interaktif sehingga dari hasil pelatihan terdapat peningkatan pemahaman baik sebelum maupun sesudah pelatihan.
\end{abstract}

\begin{abstract}
A B S T R A C T
The business with coconut husk broom made by Namira and Bina Taruna is a business that has been run by partner in Telaga Waru Village, Pringgabaya Sub-district, East Lombok Regency. The focus of this activity is how to oversee the whole process of business management, and to manage, document the production result coconut fiber through marketing media to produce output or end result to be more optimal and effective. This Partnership Program activity aims to improve the quality of coconut husk products located in Telaga Waru Village, Pringgabaya District, East Lombok Regency. Methods of implementation of the Community Partnership Program offered by the proposing team to the two partners include coordination of partner group existence, preparation of activity schedules, skills partner group development assistance, marketing through assistance, organizing of scheduled open housing products and facilitating coverage in the print media. The result of this dedication has been felt by the entire community of Telaga Waru village and surrounding area after the participants follow the process of socialization and science is given through direct practice and interactive dialogue process so that from the training result, there will be improvement of understanding before and after training.
\end{abstract}

Corresponding author.

E-mail addresses: didinimarc@gmail.com (Didin Hadi Saputra) 


\section{Pendahuluan}

Indonesia adalah negara agraris dimana sebagian besar penduduknya bekerja sebagai petani, dimana dari hasil sampingnya diperoleh diantaranya adalah sabut kelapa. Indonesia merupakan negara penghasil kelapa utama dunia (Opiyanti, 2013). Buah kelapa memiliki banyak manfaat untuk menunjang kehidupan seluruh umat manusia. Semua bagian pohon kelapa dapat dimanfaatkan untuk kehidupan kita sehari-hari. Daun kelapa dapat digunakan untuk membuat ketupat. Lidi dapat dibuat sapu dan tusuk sate serta kerajinan piring. Pelepah dan batangnya untuk kayu bakar. Air kelapa selain dapat diminum langsung, juga dapat diolah menjadi produk minuman seperti. Daging kelapa juga dapat dibuat untuk santan dan minyak goreng.Kelapa adalah tanaman serba guna karena setiap bagian tanaman bermanfaat bagi manusia, sehingga tanaman kelapa dijuluki "Tree of Life".

Pengembangan produk berbasis kelapa terus menunjukkan peluang yang berarti. Hal ini tidak terlepas dari komponen-komponen yang terkandung dalam kelapa. Pengolahan sabut kelapa sudah banyak yang dilakukan, baik diolah dari segi fisik maupun dengan menambahkan berbagai jenis larutan sehingga dapat membentuk material yang baru (Hanum, 2015). Proses pengolahan hasil kelapa berkaitan dengan pemanfaatan buah kelapa yang terdiri dari: daging kelapa, air kelapa, sabut kelapa, dan tempurung serta pemanfaatan batang dan lidi. Sedangkan menurut Samosir (1992) menyatakan bahwa sabut kelapa memiliki serat yang memiliki ciri khusus baik dari keindahan serat yang dapat dibentuk sesuai keinginan kemudian tidak mudah patah dan dapat dikombinasi dengan banyak material sehingga akan jauh lebih bernilai apabila dapat diolah kembali menjadi material baru untuk sebuah produk. Beberapa keistimewaan pemanfaatan serat sabut kelapa sebagai bahan baru rekayasa antara lain menghasilkan bahan baru komposit alam yang ramah lingkungan dan mendukung gagasan pemanfaatan serat sabut kelapa menjadi produk yang memiliki nilai ekonomi dan teknologi tinggi (Amin, 2010). Sabut kelapa jika diolah dengan optimal akan menghasilkan serat sabut kelapa dengan kualitas yang baik, memberikan nilai tambah dari sebuah sapu dan keset karena mempunyai daya tarik tersendiri berbahan serat alam (Djiwo, 2016). Segmen pasar tertentu masih membutuhkan serabut kelapa sebagai bahan utama (seperti sapu, bantal, keset dan produk lainnya) memiliki keunggulan dibandingkan produk tumbuhan yang lain.

Buah kelapa merupakan salah satu buah yang dapat dimanfaatkan secara keseluruhan mulai dari hasil utama yaitu daging buah hingga hasil sampingan yang terdiri dari air, tempurung, dan sabut kelapa. Indonesia sebagai salah satu negara yang memproduksi buah kelapa terbanyak di dunia masih tergolong kurang dalam pemanfaatan buah kelapa ini. Hal ini terbukti dengan industri pengolahan buah kelapa di Indonesia umumnya masih terfokus kepada pengolahan hasil daging buah sebagai hasil utama, sedangkan industri yang mengolah hasil samping buah (by-product) seperti air, sabut, dan tempurung kelapa masih secara tradisional dan bersekala kecil, padahal potensi ketersediaan bahan baku untuk membangun industri pengolahannya masih sangat besar (Fandy et al., 2010). Berdasarkan data dari e-smartschool, sabut kelapa merupakan bagian yang cukup besar dari buah kelapa, yaitu $35 \%$ dari berat keseluruhan buah. Sabut kelapa terdiri dari serat dan gabus yang menghubungkan satu serat dengan serat lainnya. Serat adalah bagian yang berharga dari sabut. Setiap butir kelapa mengandung serat 525 gram $(75 \%$ dari sabut), dan gabus 175 gram (25\% dari sabut). Dengan produksi buah kelapa Indonesia rata-rata 15,5 milyar butir/tahun atau setara dengan 1,8 juta ton serat sabut, dan 3,3 juta ton debu sabut (Agustian, et al., 2003; Allorerung \& Lay, 1998; Anonim, 2000; Nur, et al., 2003; APCC, 2003) maka cukup banyak material yang tersedia. Salah satu usaha untuk meningkatkan pendapatan petani kelapa adalah dengan mengolah semua komponen buah menjadi produk yang bernilai tinggi, sehingga nilai buah kelapa akan meningkat (Indahyani, 2011). Namun ketersediaan material yang cukup banyak tersebut belum dimanfaatkan untuk membangun industri pengolahan hasil samping buah kelapa terutama sabut kelapa secara optimal. Beberapa keistimewaan pemanfaatan serat sabut kelapa yang ramah lingkungan dan mendukung gagasan pemanfaatan serat sabut kelapa menjadi produk yang memiliki nilai ekonomi dan teknologi tinggi membuat kami dari tim pengusul tertarik untuk melakukan kegiatan PKM ini.

Tidak terkecuali di salah satu penghasil kelapa terbesar di Propinsi NTB, yakni di Lombok Timur, salah satu potensi di Kabupaten ini adalah di bagian usaha produksi sapu dari serat serabut kelapa. Potensi ini banyak ditemui di bagian Timur, khususnya di Desa Telaga Waru Kecamatan Pringgabaya Kabupaten Lombok Timur. Desa Telaga Waru merupakan salah satu Desa Pemekaran di Kecamatan Pringgabaya Kabupaten Lombok Timur. Desa Telaga Waru mempunyai luas wilayah 99 Ha, serta memiliki jumlah penduduk 3.862 jiwa atau 1.687 KK(Timur, \& Daerah, 2012). Seperti yang disebut diatas, sebagai hasil pemekaran, Desa Telaga Waru berasal dari sebagian wilayah Desa Bagek Papan, yang terdiri atas Dusun Benyer Daya, Dusun Benyer Lauk, Dusun Dasan Tapen Daya dan Dusun Dasan Tapen Lauk.

Jadi, dengan terbentuknya Desa Telaga Waru wilayah Desa Bagek Papan dikurangi oleh wilayah Desa Telaga Waru.Usaha Mikro Kecil dan Menengah Kelompok Namira dan Bina Taruna operasionalnya 
dilaksanakan oleh penduduk Desa Telaga Waru yang digagas oleh salah satu ketua kelompoknya, yakni untuk kelompok Namira oleh saudari Rakyah, dengan anggota masing - masing bernama Rasih, Habibah dan Sukur Wati, sedangkan dari kelompok usaha Bina Taruna di gagas oleh saudari Rustini, dengan anggota masing - masing bernama Haesum, Inaq Ati, dan Rohani. Usaha bersama kelompok Namira merupakan usaha yang telah dilakukan secara turun temurun oleh anggotanya seperti yang telah kami sebutkan di atas. Tingkat pendidikan masing - masing dari anggota kelompok usaha bersama Namira di atas rata - rata tidak tamat SD, sehingga pengelolaan manajemen operasionalnya sangat minim. Sedangkan tingkat pendidikan dari anggota kelompok usaha Bina Taruna yakni 1 orang lulusan SMP dan 3 orang lulusan SD, sehingga dalam melaksanakan seluruh operasional produk atau proses value chain nya menjadi kurang optimal, sehingga untuk melakukan diferensiasi produk untuk meningkatkan optimalisasi akses pasar kurang optimal.

Bila ditinjau dari segi produksi, selama ini kedua mitra (Kelompok Namira dan Bina Taruna), hanya mampu menghasilkan 50 s.d 200 buah sapu dari bahan serabut kelapa, dengan penghasilan perbulan berkisar antara Rp300.000,00 s.d Rp 1.200.000,00. Jadi, hasil tersebut belum mampu membuat mitra usaha Namira dan Bina Taruna mendeferensiasi produk dari bahan serabut kelapa yang nilai jual atau nilai ekonomisnya lebih tinggi dibanding saat ini. Apalagi ditambah dengan tentang pengetahuan, inovasi, serta daya kreativitas anggota Kelompok Namira dan Bina Taruna benar - benar terbatas terkait akses pasar dan jaringan pemasaran dari produk sapu berbahan serabut kelapa, terutama keluar daerah Desa Telaga Waru Lombok Timur. Berikut gambaran kedua mitra, (kelompok Namira dan mitra Bina Taruna) yakni kegiatan usaha sapu berbahan serabut kelapa.

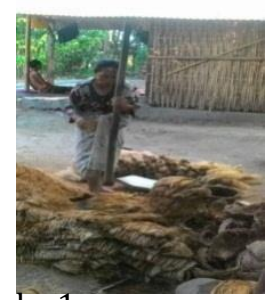

Ket gbr 1:

Sedang mencoba menumbuk kulit kelapa untuk menghasilkan serabut kelapa yang bersih dan berkualitas. Terlihat persoalan awal, alat tumbukan sederhana dan tradisional, memerlukan sentuhan teknologi tepat guna untuk mempersingkat waktu menghasilkan barang setengah jadi

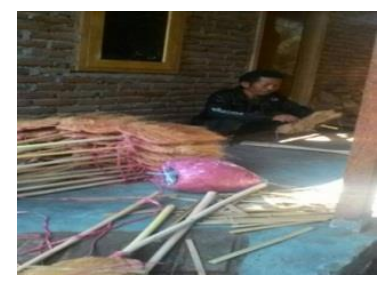

Ket gbr 6 :

Hasil produksi sapu berbahan serabut kelapa yang manajemen operasionalnya memerlukan pendampingan dan pembimbingan secara berkelanjutan
Ket gbr 2 :

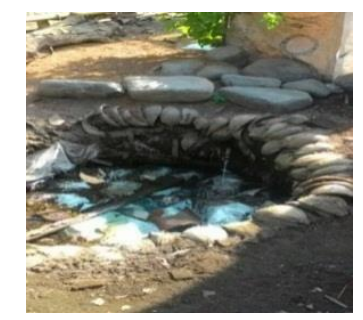

Proses pembersihan kulit kelapa setelah selesai ditumbuk, untuk memisahkan kulit dan serabut kelapa, bertujuan untuk menghasilkan serabut kelapa yang berkualitas. Masalah : wadah atau media tempat pembersihan serabut kelapa masih sangat tradisional, sehingga diperlukan media permanen sebagai tempat pembersihan kulit kelapa.

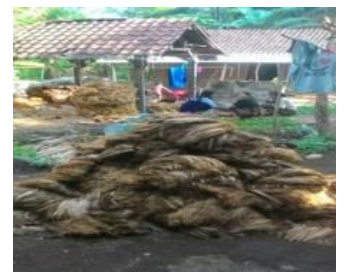

Ket gbr 3 :

Tumpukan serabut kelapa yang sudah ditumbuk

Ket gbr 4 :

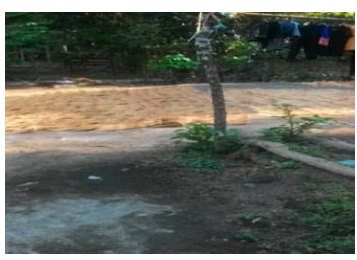

Hasil pencucian serabut kelapa dikeringkan terlebih dahulu 


\section{Kajian Literatur}

Petani tradisional di bidang perkebunan kelapa masih belum maksimal dalam pengolahan limbah kelapa terutama sabutnya, hanya beberapa penduduk yang menggunakan sabut kelapa sebagai keperluan rumah tangga seperti keset, sapu, dan sebagainya. (Rasuna, Kav, \& Selatan, 2014). Karena di beberapa Negara berkembang banyak yang menggantungkan kehidupannya pada tanaman kelapa sebagai sumber makanan, minuman, bahan bangunan, rumah, obatobatan, kerajinan tangan, bahkan kelapa juga dijadikan bahan baku pada sejumlah industri penting seperti kosmetik, sabun, dan lain lain (Kriswiyanti, 2011).

\section{Metode}

Metode pelaksanaa PKM yang dijalankan tim pengusul pada mitra Kelompok Namira dan Bina Taruna meliputi kegiatan yang dilakukan secara sistematis dan berkesinambungan serta melakukan pembinaan dan pengarahan manajemen produksi atau supply chain management melalui sosialisasi program kemitraan berbasis wilayah pemasaran, mempersiapkan dan melakukan koordinasi antara team dan mitra berkaitan dengan kegiatan yang akan dilakukan melalui penyusunan jadwal kegiatan, penentuan tempat, media yang akan digunakan untuk promosi dan materi yang dibutuhkan, melakukan pembinaan keterampilan kelompok dalam bidang manajemen dengan mengelola manajemen usaha edukatif agar lebih menarik dan layak dikunjungi, serta melakukan pendampingan pengembangan keterampilan kelompok usaha mitra dalam mempromosikan produk.

Metode pendekatan yang ditawarkan yakni sosialisasi program PKM yang dilakukan di tingkat desa dengan melibatkan kelompok mitra binaan, namun transfer teknologi akan di fokuskan pada dua kelompok sasaran yang menjadi prioritas utama, yaitu kelompok mitra kelompok Namira dan mitra Bina Taruna. Partisipasi mitra dalam pelaksanaan kegiatan dimaksudkan untuk mendukung kelancaran kegiatan yang akan dilaksanakan. Dalam proses penerapan transfer teknologi tepat guna di kedua mitra (Kelompok Namira dan Bina Taruna) melalui program PKM Kemenristek Dikti, hal yang didapat dari partisipasi mitra binaan yaitu mitra binaan dapat menerima dan menerapkan aplikasi atau praktik pembuatan sapu berbahan serabut kelapa dengan menggunakan teknologi tepat guna, tanpa mengabaikan kualitas dari produk mereka sendiri. Oleh sebab itu, diperlukan upaya melakukan pengembangan untuk berpikir kreatif, hal ini dimaksudkan bahwa melalui kegiatan PKM, mampu menghasilkan wirausaha mandiri yang saling melengkapi, mampu mengatasi permasalahan yang dihadapi dan mampu mengembangkan kreativitasnya untuk memanfaatkan setiap potensi dan peluang yang diketahui untuk memperbaiki mutu hidupnya.

Agar program dapat diterapkan dengan baik, maka sangat diperlukan proses penyuluhan dua arah, dimana partisipasi mitra dalam hal ini sangat diperlukan agar mereka merasa bahwa program ini memang berguna bagi mereka sehingga dalam penyampaian dan praktiknya dapat efektif dan efisien.Secara konsep, pendidikan dan latihan adalah sistem pendidikan di luar sekolah (non formal), bagi kedua mitra dan masyarakat sekitar agar berubah dan berkembang pola fikirnya menjadi pengrajin yang mengoptimalkan teknologi dalam menjalankan usahanya, wirausaha lebih menguntungkan (better bussines), hidup lebih sejahtera (better living), dan bermasyarakat lebih baik (better community) serta menjaga kelestarian lingkungannya (better environment).

\section{Hasil dan pembahasan}

Kegiatan pengabdian masyarakat di Dusun Benyer, Desa Telaga Waru, Kecamatan Pringgabaya merupakan kegiatan yang dilakukan oleh tim pengabdian Universitas Nahdlatul Wathan Mataram. Kegiatan pengabdian ini merupakan kegiatan pengabdian yang di fasilitasi oleh Direktorat Riset dan Pengabdian Masyarakat (DRPM) Kementerian Riset dan Teknologi Pendidikan Tinggi. Dalam pelaksanaan kegiatan Program Kemitraan Masyarakat ini, tim pengabdian dari Universitas Nahdlatul Wathan Mataram (berjumlah 3 orang), serta 3 orang mahasiswa di bidang Administrasi dan Ekonomi turut serta dalam pengabdian ini.Dalam proses pengabdian ini, perkembangan mitra ke dua mitra binaan setelah adanya pelatihan tentang potensi sapu berbahan serabut kelapa yang produksinya menggunakan teknologi tepat guna sudah semakin baik, misalnya alat penumbuk kulit kelapa yang menggunakan mesin untuk pemisahan serabut kelapa, bukan alat tumbuk manual (lihat gambar), sehingga secara ekonomi akan lebih praktis dan menghemat tenaga serta waktu. Kemudian pelatihan kepada anggota mitra yang tergabung dalam dua kelompok mitra dengan melatih membuat produk anyaman lain yang bernilai ekonomi tinggi. Pembuatan produk atau deferensiasi produk inovatif berbahan serabut kelapa lainnya akan melibatkan pengusul PKM, kelompok mitra PKM dan Penyuluh dari Dinas Koperasi dan UMKM. 
Dalam kegiatan pengabdian tersebut, mitra PKM yakni Kelompok Namira dan Bina Taruna turut serta berperan aktif didalam proses pelatihan maupun pendampingan oleh tim PKM. Masing - masing anggota Namira dan Bina Taruna.

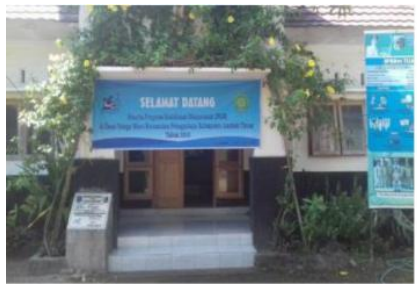

Ket gbr 1 :

Lokasi pelatihan mitra PKM (Kelompok Namira dan Bina Taruna, Dusun Benyer Desa Telaga Waru, Pringgabaya Lombok Timur

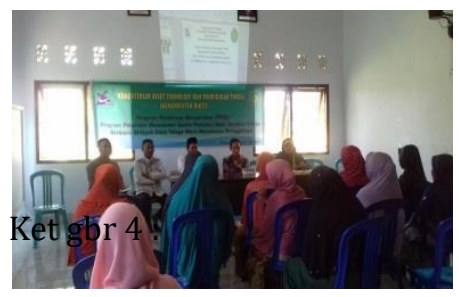

Para pembicara, peserta, aparatur desa serta para anggota mitra yang sedang mengikuti pelatihan manajemen usaha sapu serabut kelapa

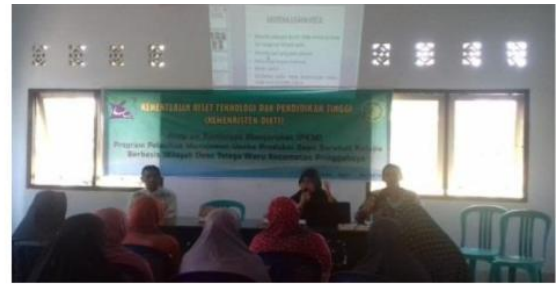

Ket gbr 2 :

Pembicara dari tim PKM sedang memberikan materi terkait dengan proses manajemen serta operasional produk sapu serabut kelapa

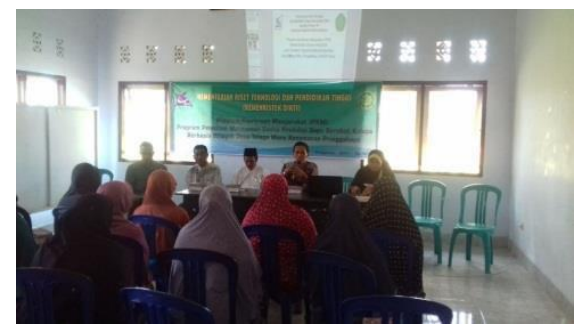

Ket gbr 3 :

Pemateri yang menguraikan tentang seluruh proses atau tahapan dalam PKM, menguraikan tentang syarat peserta, syarat lembaga penyelenggara, syarat produk mitra, serta proses tindak lanjut Program Kemitraan Masyarakat (PKM) kedepan bersama mitra, serta masyarakat Dusun Benyer Desa Telaga Waru pada umumnya.

Dalam kegiatan PKM tersebut diungkapkan berbagai macam keluhan yang ditemui oleh para mitra melalui diskusi dan tanya jawab, yakni, sulit serta lamanya proses perendaman bahan baku utama sapu, yakni serabut kelapa yang masih utuh (sudah terpisah dari buah kelapa), kemudian tempat atau sarana dan peralatan pendukung operasional mitra, serta keterbatasan proses pemasaran dari produk sapu serabut kelapa. Setelah melalui pendampingan serta pembinaan yang efektif, akhirnya tim dari PKM Universitas Nahdlatul Wathan Mataram sepakat sesuai dengan peta tahapan awal untuk memandu serta membina para mitra untuk dapat lebih optimal untuk memasarkan produknya, baik melalui offline maupun online.

Pendampingan dan pembinaan berbasis wilayah yang dilakukan oleh tim PKM Universitas Nahdlatul Wathan Mataram meliputi membantu pengadaan peralatan utama yang digunakan untuk memisahkan serabut kelapa dengan kulitnya, yang nantinya bahan utama tersebut akan diolah kembali menjadi bahan setengah jadi, serta outputnya barang jadi berupa sapu berbahan serabut kelapa. Kegiatan pendampingan tersebut juga meliputi kegiatan penerapan manajemen usaha dan pengelolaan keuangan UKM mitra, sehingga kegiatan ini diharapkan dapat berdampak kepada ketertiban kegiatan opera sional usaha mitra, dan keutuhan dalam mengelola serta meningkatkan kapasitas produksi sapu dengan baik.

Salah satu yang paling banyak dikeluhkan oleh mitra PKM adalah keterbatasan sumber akses modal usaha UKM mitra, keterbatasan ini disebabkan oleh kurangnya akses pasar, kurang dan lemahnya akses permodalan, serta kurangnya akses informasi mitra dengan jaringan pemasaran, jaringan permodalan, serta jaringan mitra bisnis yang lebih luas, sehingga proses pelebaran atau pengembangan pemasaran yang dialami oleh mitra terkesan sempit, bahkan bergerak di seputaran desa setempat saja. Oleh karena itu, dalam mengatasi hal tersebut, diperlukan adanya penguatan serta pengembangan yang berbentuk rekayasa sosial berbasis wilayah, namun mempunyai akses secara nasional. Sehingga setelah proses penguatan pendampingan serta pembinaan ini berjalan, nantinya ada pengintegrasian yang lebih luas lagi 
terhadap pengelolaan keuangan/usaha dan cara mengakses tambahan modal kerja UKM mitra dengan dunia industri yang berhubungan dengan handmade product.

Untuk lebih meningkatkan dan lebih membuka akses pasar serta akses bisnis mitra PKM, diperlukan adanya sistem rekayasa sosial yang lain, dengan tujuan untuk lebih ter explore dan ter ekspose nya produk dusun Benyer desa Telaga Waru, membuka saluran disitribusi pemasaran yang baik sangat diutamakan oleh tim PKM Universitas NW Mataram, saluran distribusi pemasaran tersebut berupa outlet atau showroom yang menampilkan hasil produk masyarakat dusun Benyer desa Telaga Waru. Outlet atau showroom inilah yang belum berfungsi dengan baik, sehingga upaya promosi yang maksimal terutama ke luar Desa Telaga Waru belum optimal dilakukan. Ruang produksi dan penyimpanan produk juga masih terkesan sangat sederhana, sehingga perlu pembenahan secara keseluruhan terhadap administrasi, produksi, penyimpanan dan pemasaran pada UKM mitra (Kelompok Namira dan Bina Taruna).

Peningkatan kuantitas dan kualitas kerja para pengrajin atau pekerja sapu serabut kelapa juga perlu ditingkatkan, agar nantinya dalam membuka akses atau jaringan pemasaran, mereka dapat berkomunikasi dengan baik, karena untuk berkomunkasi dengan para calon pembeli, diperlukan proses komunikasi pemasaran yang baik serta memahami komunikasi personal dengan utuh, sehingga kegiatan pendidikan dan latihan (Diklat) harus rutin diadakan sehingga nantinya kegiatan pelatihan, baik manajemen usaha, teknik membuat product yang lebih inovatif, teknik modifikasi warna sapu serabut kelapa maupun jangkauan pemasarannya lebih luas lagi.

Kegiatan penampingan serta pembinaan ini berlangsung selama mitra memperoleh program PKM dari Kemenristek Dikti yang di percayakan pelaksaannya kepada Universitas Nahdlatul Wathan Mataram, dan kegiatan pendampingan dan pembinaan ini akan berlanjut selamanya, dengan tujuan kedua mitra akan mampu lebih mandiri dalam menjalankan usaha sapunya, serta lebih mandiri dan mampu dalam membina mitra yang lain yang ada di lingkungan Desa Telaga Waru Pringgabaya Lombok Timur. Salah satu kriteria penting dalam mengevaluasi kelayakan dari program kemitraan masyarakat ini adalah kemampuan dari alat yang bersangkutan dalam mendatangkan keuntungan serta kemauan mitra untuk terus meningkatkan kapasitas produksi, peningkatan keuntungan, rekayasa sosial yang komprehensif, serta output lainnya yang mendatangkan banyak manfaat serta keuntungan, baik buat penyelanggara PKM (Universitas NW Mataram), mitra PKM (Kelompok Namira dan Bina Taruna), serta pemberi dana PKM (DRPM/Kemenristek Dikti). Hasil masa operasi selama ini yang dilakukan oleh kedua mitra menunjukkan potensi yang layak untuk dikembangkan secara lebih luas lagi

\section{Simpulan dan saran}

Usaha bersama sapu berbahan baku serabut kelapa yang dijalankan oleh Kelompok Namira dan Bina Taruna merupakan usaha yang telah dijalankan oleh mitra kami di Desa Telaga Waru Kecamatan Pringgabaya Kabupaten Lombok Timur. Usaha tersebut telah dilaksanakan secara turun temurun oleh warga desa setempat. Tim pelaksana kegiatan telah bekerjasama dengan tim praktisi, dan dinas terkait dengan memaksimalkan fungsi tim pelaksana kegiatan dalam mendampingi pengrajin dan unit usaha, sehingga mempunyai kemampuan dan ketrampilan yang dapat digunakan untuk meningkatkan kualitas serta hasil produksi sapu berbahan serabut kelapa di Desa Telaga Waru Kecamatan Pringgabaya dan diharapkan dapat menunjang peningkatan daya beli masyarakat dan peningkatan perekonomian dari daerah Nusa Tenggara Barat.

\section{Daftar Rujukan}

Agustian, A., Friyatno, S., Supadi, \& Askin, A. (2003). Analisis pengembangan agroindustri komoditas perkebunan rakyat (kopi dan kelapa) dalam mendukung peningkatan daya saing sektor pertanian. Makalah Seminar Hasil Penelitian Pusat Penelitian dan Pengembangan Sosial Ekonomi Pertanian Bogor. T.A. 2003. 38 hal

Allorerung, D., \& Lay, A. (1998). Kemungkinan pengembangan pengolahan buah kelapa secara terpadu skala pedesaan. Prosiding Konperensi Nasional Kelapa IV. Bandar Lampung 21 - 23 April 1998 Pp.327 - 340 .

Anonim (2000). Hasil pengkajian sabut kelapa sebagai hasil samping. Jakarta: Bank Indonesia. 15 hal. Amin, Muh, Samsudi R. 2010. Pemanfaatan Limbah Serat Sabut Kelapa Sebagai Bahan Pembuat Helm Pengendara Kendaraan Roda Dua. Prosiding Seminar Nasional Unimas hal 314-318 
Andini, S., \& Widiawati, D. (2014). Pemanfaatan Sabut Kelapa dan Pewarna Alam Indigofera Sebagai Material Alternatif pada Produk Kriya. Jurnal Tingkat Sarjana Bidang Senirupa Dan Desain.

Dewi, Shinta dan Indah Nurhayati . (2012) . "Sabut Kelapa Sebagai Penyerap Cr (IV) Dalam Air Limbah ." Jurnal Teknik Waktu. Vol 10 No. 10, 23-27.

Djiwo, Soeparno, Eko Yohanes Setyawan. 2016. Mesin Teknologi Tepat Guna Sabut Kelapa Di Ukm Sumber Rejeki Kabupaten Kediri. SENASPRO 2016, Seminar Nasional dan Gelar Produk hal 576582.

Hanum, Maulia Shofiyah. 2015. Eksplorasi Limbah Sabut Kelapa ( Studi Kasus : Desa Handapherang Kecamatan Cijeunjing Kabupaten Ciamis). e-Proceeding of Art \& Design : Vol.2, No.2 hal. 930-938

Indahyani, Titi. 2011. Pemanfaatan Limbah Sabut Kelapa Pada Perencanaan Interior Dan Furniture Yang Berdampak Pada Pemberdayaan Masyarakat Miskin. H U M A NIO R A Vol.2 No.1 hal 15-23

Menurut, L. B., Akuba, M., Riau, P., \& Tenggara, N. (1997). Abstrak, 1-9.

No, V. (2014). Jiia, Volume 2 No. 2, April 2014, 2(2), 133-141.

Opiyanti, M.R Yantu, Sisfahyuni . 2013. Analisis Nilai Tambah Serabut Kelapa Sebagai Bahan Baku Pembuatan Aneka Produk (Kasus Pt. Sumber Utama Lesari Kecamatan Tanantovea Kabupaten Donggala). J. Agroland 20 (2) : 138 - 145

Program, M., Teknik, S., Universitas, S., Petra, K., Program, M., Teknik, S., ... Petra, K. (2006). Pengaruh pemanfaatan serat sabut kelapa dengan perlakuan alkali terhadap kuat tekan dan kuat tarik beton, $1-8$.

Rasuna, J. H. R., Kav, S., \& Selatan, J. (2014). Memperkuat posisi koperasi dan ukm dalam rantai pasok global untuk komoditi serat sabut kelapa, 1-12.

Samosir, Y. (1992) . Asal usul Penyebaran Kelapa, dalam Kelapa (Cocos nucifera, L), Asosiasi Litbangbun, Puslitbun Marihat_Bandar Kuala Pematang Siantar.

Timur, K. L., Timur, L., \& Daerah, P. (2012). Pemerintah kabupaten lombok timur, 19, 1-23.

Wulandari, S. (2009). Analisis Peluang Dan Tantangan Pengembangan Agroindustri Kelapa, 4 (1), 28-38. 